\title{
Seasonal climatic forcing of alpine glaciers revealed with orbital synthetic aperture radar
}

\author{
Laurence C. Smith, ${ }^{1 *}$ Righard R. Forster, ${ }^{1 \dagger}$ Bryan L. Isacks, ${ }^{1}$ Dorothy K. Hall ${ }^{2}$ \\ ${ }^{1}$ Department of Geological Sciences, Cornell University, Ithaca, New York 14853, U.S.A. \\ ${ }^{2}$ NASA/Goddard Space Flight Center, Hydrological Sciences Branch, Laboratory for Hydrospheric Sciences, \\ Code 974, Greenbelt, Maryland 20771, U.S.A.
}

\begin{abstract}
The evolution of four dynamic radar glacier zones at the surface of an alpine iccfield in British Columbia is monitored using a time series of 35 First European Remote Sensing Satellite (ERS-1) synthetic aperture radar (SAR) images acquired from 1992 to 1994. These zones result from changing wetness and textural properties, and appear to represent: (1) cold snow with no liquid water present; (2) an initial melt front with an upper boundary near the elevation of the $0^{\circ}$ isotherm; (3) metamorphosed, rapidly melting first-year snow with a rough or pitted surface; and (4) bare ice. This interpretation is aided by temperature and runoff data, air photographs and field measurements of snowpack properties acquired simultaneously with two ERS-1 SAR scenes, ice-surface elevations derived from 1:50 000 topographic maps and simulations of radar backscatter from a geometric optics model of surface scattering. Meltwater production is affected by the development of zones (2), (3) and (4), which form, migrate up-elevation and disappear each year between April and September.
\end{abstract}

\section{INTRODUCTION}

Most of the world's alpine glaciers have been retreating during the last 100 years (Meier, 1984; Haeberli and others, 1989), contributing an estimated one-third to one-half of a $10-15 \mathrm{~cm}$ rise in sea level observed since 1900 (Meier, 1984). Shrinking ice volumes have increased the risk and incidence of landslides and glacier-outburst floods in mountainous areas (O'Connor and Costa, 1993) and will have an uncertain effect upon water supply from glacier-fed streams. It is clear that more observations of glacier mass balance, melt patterns and snowline position are needed for climate monitoring, natural hazard assessment and water-supply purposes. New techniques for monitoring glaciers with orbital synthetic aperture radar (SAR) will complement existing field programs and also permit temporal study of remote sites where glacier conditions are currently known. SARs penetrate cloud cover and darkness to permit frequent observation of dynamic, climate-sensitive properties at the glacier surface and near-surface.

Knowledge of the timing and volume of meltwater runoff is required for effective management of regulated basins wherever humans and glaciers coexist. For this reason, numerous watershed runoff models have been developed that use meteorological data to predict meltwater production, storage and release from glacial sources (Young, 1985). The amount of melting at the glacier or snowpack surface is a key calculation in all such models. This process is rarely

* Now at Department of Geography, University of California, Los Angeles, California 90095-1524, U.S.A.

* Now at Byrd Polar Research Center, The Ohio State University, Columbus, Ohio 43210, U.S.A. measured directly; melt rates are instead calculated using an energy-balance approach with ground meteorological observations (see Young, 1985). This approach works well where meteorological data are available near the study glacier but worsens rapidly when data are extrapolated from distant stations. Regardless of station location, the spatial distribution of melt is assumed to vary as a function of elevation or is modeled using a digital elevation model to calculate the energy balance at each gridpoint on the glacier surface. This limitation has hampered development of physically based distributed runoff models designed to predict glacier runoff.

Due to its sensitivity to the presence of liquid water, SAR has strong potential for directly mapping patterns of snowmelt (Donald and others, 1993; Fahnestock and others, 1993; Hallikainen and others, 1993; Rott and Nagler, 1993; Shi and Dozier, 1993; Maxfield, 1994). Estimates of snow wetness may be retrieved using polarimetric C-band SAR data with a backscattering model that considers both surface and volume scattering (Shi and Dozier, 1992, 1995; Shi and others, 1993). However, relief-induced distortions in SAR data can severely limit snow-cover mapping in areas of rugged terrain (Haefner and others, 1994; Rott, 1994). Over glaciers, areas of wet snow may be observed in SAR imagery from their low backscatter returns (Rott and Mätzler, 1987; Bindschadler and Vornberger, 1992). Other surface conditions may also be observed. Fahnestock and others (1993) mapped four distinct zones on the Greenland ice sheet using ERS-1 (First European Remote Sensing Satellite) SAR imagery. They were interpreted as corresponding to the dry-snow, percolation, wet-snow and bare-ice glacier facies defined from field measurements by Benson (1962). High backscattering from icy inclusions buried in the percolation zone during cold conditions has since been success- 
fully modeled as randomly oriented dielectric cylinders embedded in a dry-snow medium (Rignot, 1995). Forster and others (1996) used polarimetric SIR-C/S-SAR data to identify climatically driven intra-annual changes in glacier-surface and near-surface conditions in Patagonia. Several multi-temporal ERS-1 SAR studies of glaciers have reported dramatic temporal and spatial variations in backscattering properties related to glacier-surface conditions (Rott and Nagler, 1994; Hall and others, 1995; Rees and others, 1995).

This study presents temporal analyses of 35 ERS-1 SAR images acquired from 1992 to 1994 over an iceficld and two outlet glaciers in British Columbia, Canada. Four dynamic zones controlled by conditions of melting and texture are seen in the SAR data. Next, these zones are correlated with daily ground measurements of temperature and runoff in 1992 and 1993, air photographs and field measurements taken during two 1994 ERS-1 SAR acquisitions and ice-surface elevations derived from 1:50000 topographic maps. Finally, simulated radar backscatter values from a simple geometric optics model of radar backscattering are compared with ERS-1 backscatter values from the study glaciers and a nearby snowpack. Model inputs include field measurements of snow properties made within hours of an 8June 1994 ERS-1 SAR acquisition.

\section{THE STIKINE ICEFIELDS, BRITISH COLUMBIA}

The Coast Range of Alaska and British Columbia is one of the most extensively glacierized regions on Earth, with $88400 \mathrm{~km}^{2}$ of glacier ice (Meier, 1984). Glacier mass balance and annual equilibrium-line altitudes in this area may be used as climatic indicators (Pelto, 1987). Because the weather conditions during the accumulation season are controlled by a shifting boundary between the Aleutian Low and the Canadian Polar High (Yarnal, 1984), the annual mass balance of glaciers in this area is particularly sensitive to winter atmospheric conditions. Pelto (1989) found a strong correlation between the occurrence of winter cyclonic passages and positive mass balances estimated for 90 glaciers in the region.
The Stikine icefields are found in the southern part of the Coast Range. Part of the largest icefield, including two outlet glaciers $\left(56^{\circ} 55^{\prime} \mathrm{N}, 131^{\circ} 00^{\prime} \mathrm{W}\right)$, was selected for repeated SAR imaging by the ERS-1 satellite (site 1, Fig. 1). The maximum elevation of this icefield is approximately $1850 \mathrm{~m}$; the outlet-glacier termini are both near $580 \mathrm{~m}$. Daily mean air temperatures at $640 \mathrm{~m}$ were observed $30 \mathrm{~km}$ away at Bob Quinn Lake. Daily mean meltwater discharge was measured by a Water Survey of Canada gauge located on Forrest Kerr Creek, $11 \mathrm{~km}$ downstream of its emergence from the two outlet glaciers. Locations of the discharge and temperature stations are shown in Figure 1.

The drifting orbit of ERS-l during its 1994 geodetic mission allowed ascending and descending SAR acquisitions within a 37 hour period on 8 and 9 June. Helicopter transport to a nearby non-glacierized snowpack (site 2, Fig. 1) permitted measurements of snowpack wetness, surface roughness, grain-size, depth and temperature to be made within hours of the 8 June SAR acquisition. Discharge measurements of meltwater runoff in Bronson Creek, the primary drainage from this snowpack, were collected on 31 May and 1, 3, 5, 6 and 10 June. Hand-held oblique air photographs over the study icefield and outlet glaciers were acquired within minutes of the 9 June descending orbit.

\section{THE ERS SATELLITES AND DATA PROCESSING}

ERS-1 was launched on 17 July 1991 by the European Space Agency and placed in adjustable near-circular polar orbit. It has experienced 3,35 and 168 day repeat cycles during its various mission phases. Converging orbits at high latitudes permit overlapping scenes to be obtained more often. ERS-1 uses a C-band $(5.3 \mathrm{GHz})$ SAR with vertical transmit and receive $(\mathrm{VV})$ polarizations and a look angle of $23^{\circ}$, producing an $80-103 \mathrm{~km}$ swath with a nominal spatial resolution of $25 \mathrm{~m}$ and a processed pixel spacing of $12.5 \mathrm{~m}$

From April 1992 toJune 1994, 35 descending ERS-1 SAR acquisitions of the study site were downloaded by NASA's Alaska SAR Facility (ASF) in Fairbanks, Alaska. Four scenes acquired during the 1994 Geodetic Phase were also used for comparison with field observations. Each scenc

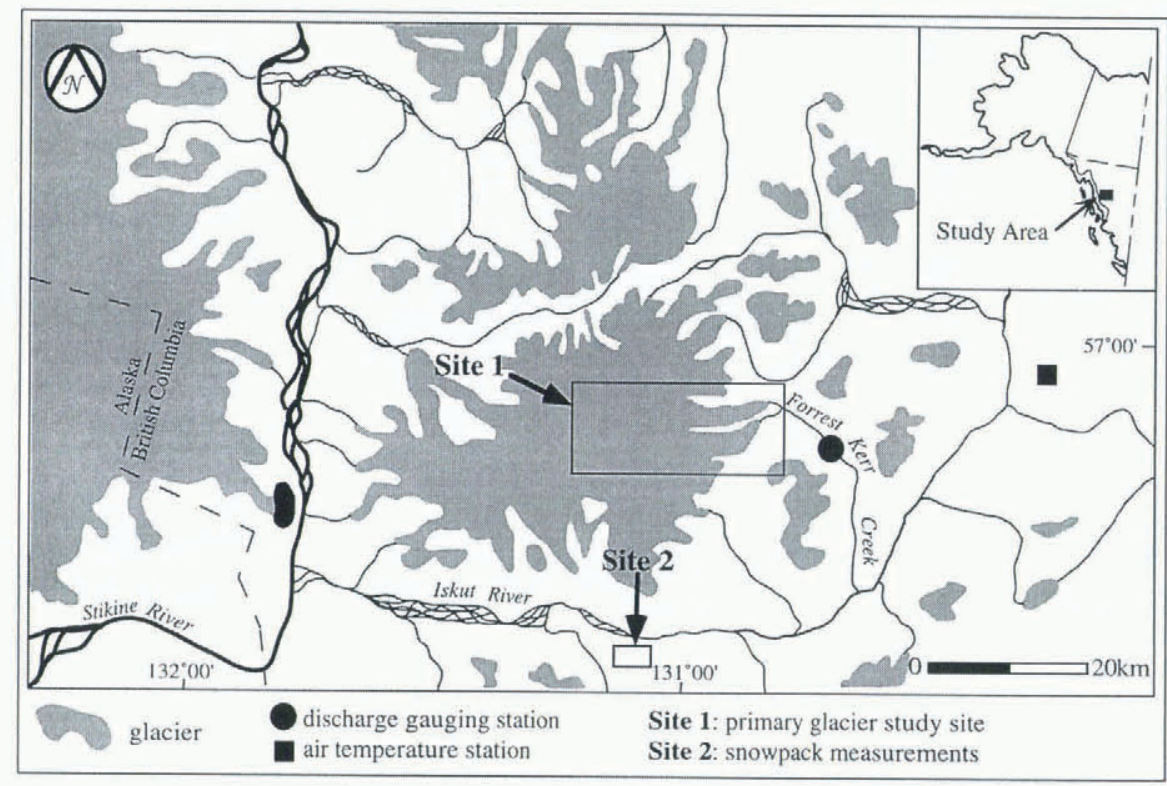

Fig. 1. Stikine icefields, British Columbia, Canada. Locations of study sites and ground temperature and discharge stations are also shown. 
was radiometrically calibrated using ASF-provided software to permit comparison of normalized radar backscatter $\left(\sigma^{\circ}\right)$ at different times and also within a single scene. The calibration process removes variations in $\sigma^{\circ}$ caused by sensor-antenna pattern, range-to-target and look angle, using a satellite-derived noise vs range function and three calibration coefficients (Bicknell, 1992). Corrections are fitted to the Goddard Earth Model (GEM06) geoid. Image speckle was next reduced for each image, using a $5 \times 5$ median filter. Rees and others (1995) showed that this process reduces the image local standard deviation in backscatter by nearly $80 \%$, while increasing the apparent mean backscatter by only $0.7 \mathrm{~dB}$. In comparison, backscatter fluctuations due to changing glacier-surface conditions vary as much as $19 \mathrm{~dB}$ over the study site. A transect of filtered backscatter values between the terminus of an outlet glacier and the icefield interior was extracted for each ERS-1 SAR image; these results are presented in the next section.

\section{RESULTS}

4.1. Time trends in ERS-1 SAR backscatter returns over glaciers

The ERS-1 time series reveals four distinct zones which may be identified by their backscatter characteristics and elevational positions with respect to each other. Following the convention of Forster and others (1996), we refer to them as radar glacier zones. Radar glacier zones are dynamic on the time-scale of days to weeks and should not be confused with glacier facies which are based upon properties integrated over time periods of years (Benson, 1962). The four radar glacier zones observed at the study site appear to represent conditions of (1) cold, dry winter snow (hereafter called "dry"); (2) snow that is just beginning to melt (hereafter called "M" for "melt front"); (3) a second phase of wet snow that is probably metamorphosed, roughened and rapidly melting (hereafter called "P2", see below); and (4) bare ice (hereafter called "bare"). Some general characteristics of these four radar glacier zones are summarized in Table 1. The ranges in $\sigma^{\circ}$ values are derived from characteristic backscatter transects through each zone.

The temporal evolution of the four radar glacier zones is shown in Figure 2, using images acquired on 20 May, 13 July

Table 1. Description of the four radar glacier zones seen in the ERS-1 SAR time series. "Label" is the zone name, as annotated in Figure 2

Label $\sigma^{\circ}$ range juxtaposition Interpretation

$\mathrm{dB}$

Dry -3 to -7 Above "M" Cold winter snow with no liquid water present

M -11 to-22 Below "dry", Initial melting of snowpack; upper above "P2" boundary found near 0 C isotherm elevation

P2 - 6 to -8 Below "M", Metamorphosed and roughened melting above "bare" snow

Bare -10 to-12 Below "P2" Bare glacier ice

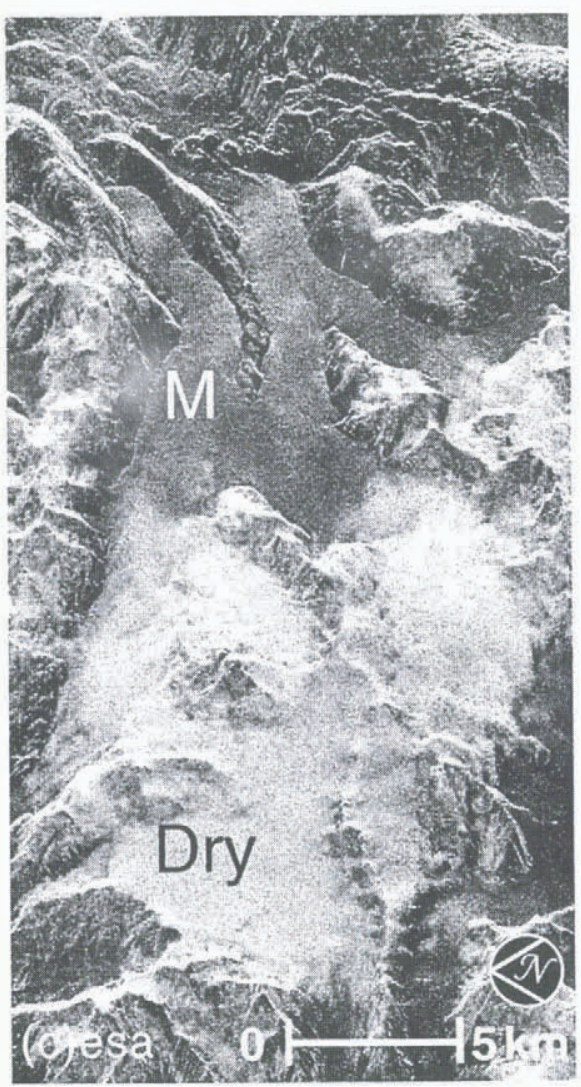

20 May 1992

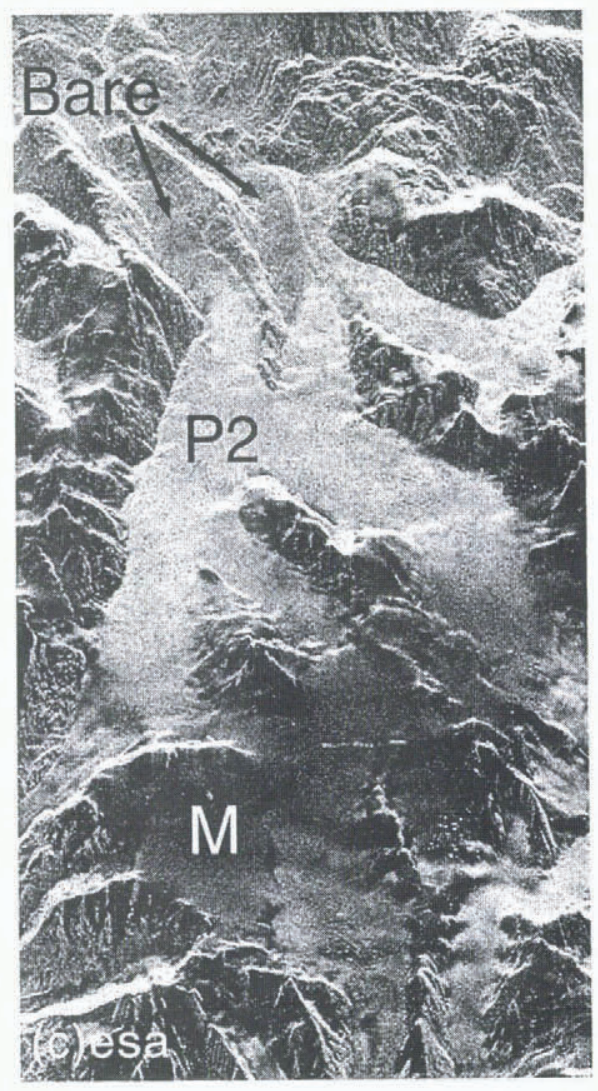

13 July 1992

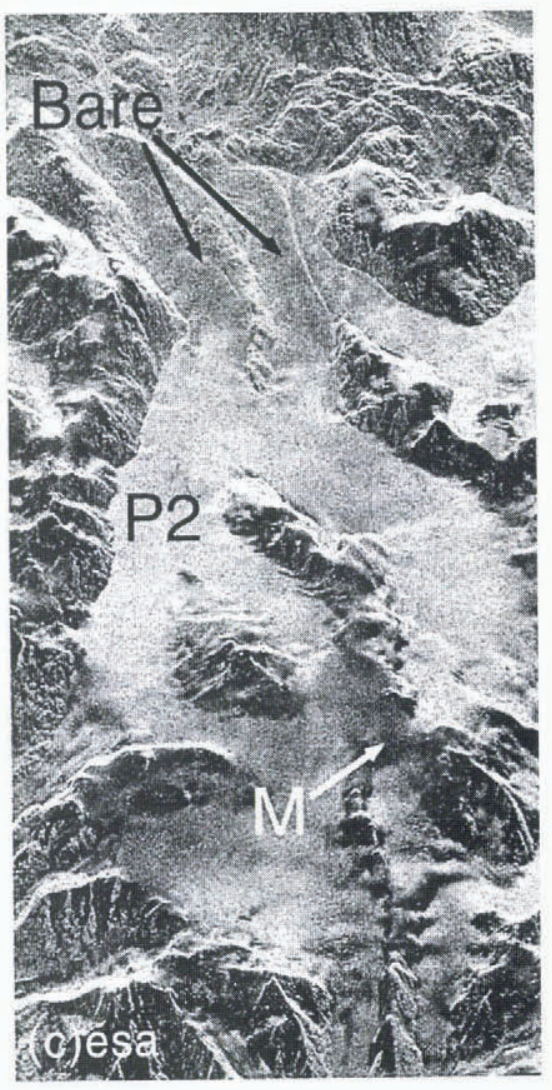

29 July 1992

Fig. 2. Development and upslope migration of four radar glacier zones revealed by the ERS-1 SAR. These zones are interpreted as: (1) cold winter snow with no liquid water present (dry); (2) initial snowmelt ( $M$ ), with an upper limit around the $0^{\circ} \mathrm{C}$ isotherm; (3) rapidly melting, metamorphosed and roughened snow cover (P2); and (4) bare ice. SAR illumination is from the top of each image. 
and 29 July 1992. The icefield interior found near the bottom of each image) slopes downward toward a pair of outlet glaciers. During the winter (not shown in Fig. 2), the entire ice surface is characterized by relatively high $\sigma^{\circ}$ values $(-3$ to $-7 \mathrm{~dB})$. On 20 May, the icefield interior still exhibited the bright radar returns of this "dry" zone (see Fig. 2). However, at lower elevations the initiation of surface melting (labeled "M" in Fig. 2) is indicated by low radar returns $(-11$ to $-22 \mathrm{~dB})$. By 13 July, this melting snow (which appears dark on the images) has risen to the elevation of the icefield interior. The bright "dry" zone has disappeared from even the highest elevations and melting is now occurring everywhere on the icefield. However, at lower elevations, a new radar glacier zone has formed which is characterized by higher values of $\sigma^{\circ}(-6$ to $-8 \mathrm{~dB})$, not unlike the returns from the "dry" zone. Because of the low elevation, conditions are known to be melting for this zone of high $\sigma^{\circ}$. As will be explained later, the high returns are likely due to multiplepath surface scattering. Roughness elements are inferred to be centimeter-scale, on the order of the $5.66 \mathrm{~cm}$ wavelength of the ERS-I SAR instrument. This part of the icefield is also below the annual firn limit (i.e. the snow is no older than the previous melt season). This high-backscatter zone is therefore interpreted as a rapidly melting first-year snowpack with a metamorphosed, roughened surface that is quite wet; we here suggest the term "phase 2 melt" or "P2" for this third type of radar glacier zone. At the time of writing, such bright radar returns from a wet, first-year snow cover have not been reported over alpine glaciers. Both observations and modeling indicate that increasing the surface roughness and/or wetness of a wet snowpack will increase $\sigma^{\circ}$ (Shi and Dozier, 1992; Jezek and others, 1993; Rott and Davis, 1993; Dowdeswell and others, 1994) but not to levels high enough to explain the -6 to $-8 \mathrm{~dB}$ returns observed over the $\mathrm{P} 2$ zone. High $\sigma^{\circ}$ has been observed over melting firn (Rott and Nagler, 1994) but at levels 4-6 dB below those characteristic of P2. Rees and others (1995) noted high ERS-1 SAR returns near the margins of the Austfonna ice cap, Svalbard, but these were interpreted as bare, heavily dissected ice. Bright ERS-1 returns can also be seen on Brúarjökull, Iceland (Hall and others, 1995) but have not been interpreted.

A fourth zone (labeled "bare" in Fig. 2) with backscatter values $(-10$ to $-12 \mathrm{~dB})$ between those of the $\mathrm{M}$ and $\mathrm{P} 2$ radar glacier zones can be seen immediately down-glacier from the P2 zone on 13 and 29 July ERS-1 SAR images. Its upper boundary moves steadily up-glacier throughout the melt season and it is not replaced by any new type of radar signature. This zone is interpreted as bare glacier ice. The interface between the bare and P2 zones is therefore believed to represent the position of the summer snowline, which steadily rises in elevation throughout the summer. By 29 July, almost all of zone $\mathrm{M}$ in the icefield interior has metamorphosed into $\mathrm{P} 2$ and at lower elevations $\mathrm{P} 2$ has been replaced in turn by bare ice.

An oblique hand-held air photograph of the study site and an ERS-1 SAR image acquired moments later are shown in Figure $3 \mathrm{a}$ and b. Cloud shadows create a mottled appearance over part of the air photograph. Although the glacier surface was observed to be completely snow-covered and featureless except near the terminus, the ERS-l SAR image reveals a distinct interface between the dark $\mathrm{M}$ zone and a developing P2 zone. This confirms that (1) SAR can identify variations in glacier-surface conditions that cannot

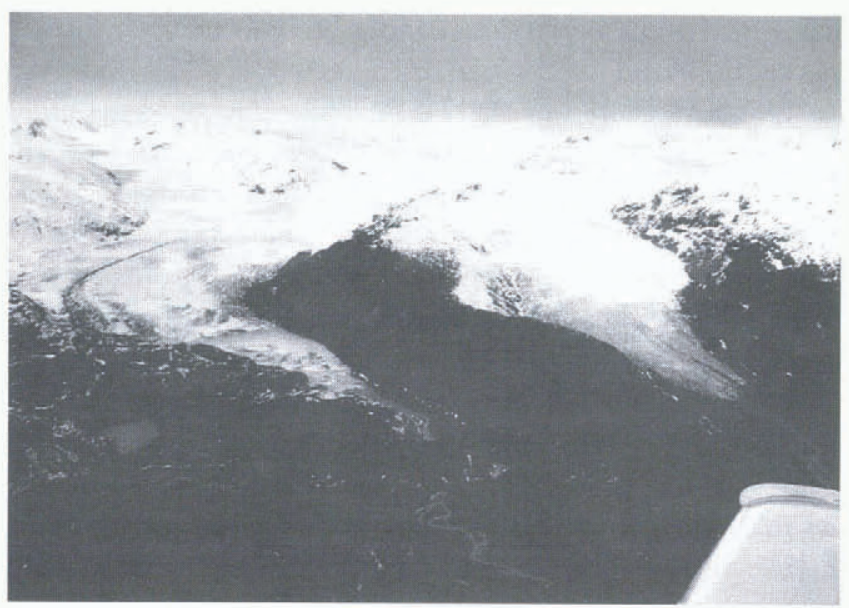

a

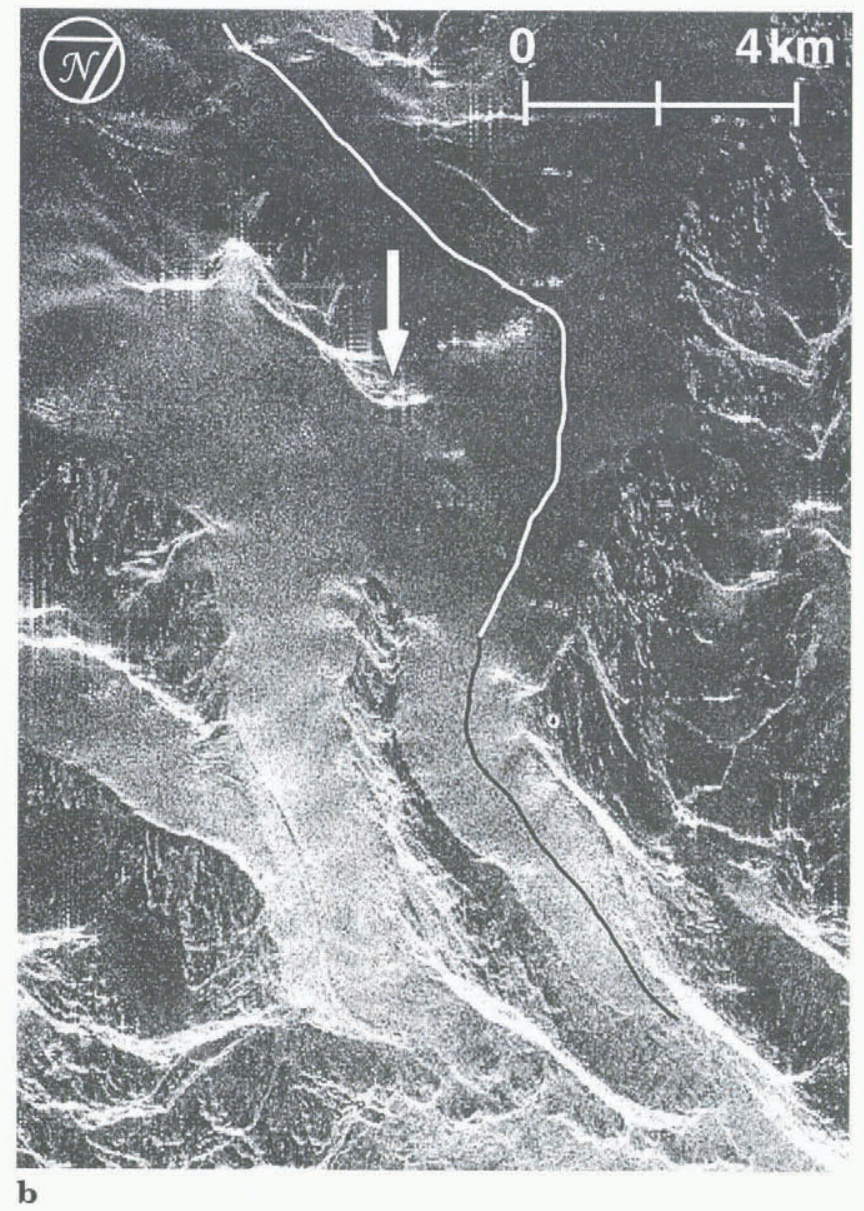

Fig. 3. (a) Hand-held oblique air photograph of the study icefield and outlet glaciers acquired within minutes of the ERS-I $S A R$ acquisition shown in (b). Mottled appearance al left is from cloud shadows. Arrow points to nunatak for reference in (b). (b) ERS-I SAR image of the area photographed in (a), revealing an interface between a low-return initial melt ( $M$ ) and a developing $P 2$ radar glacier zone. This interface cannot be seen in the air photograph (note reference arrow at nunatak). Transect used to derive backscatter profiles in Figure 4 is also shown. SAR illumination is from the bollom of the image.

be seen in air photographs, and (2) the relatively bright P2 radar returns described earlier are not produced by bare glacier ice. Furthermore, since the bright P2 region in Figure $3 \mathrm{~b}$ is well below the annual firn limit, it is also concluded that (3) these P2 returns are produced from a firstyear melting snowpack, not firn. The beginnings of a bare- 
ice zone on one outlet glacier can be seen in both the air photograph and the SAR image.

Our interpretation of the four radar glacier zones illustrated in Figure 2 is based upon the complete ERS-1 SAR time series over the study site. These scenes show the up-elevation migration of the four zones to be continuous and consistent throughout the 1992 and 1993 melt seasons (AprilSeptember). Radar backscatter transects from the terminus of one outlet glacier to the icefield interior are presented for all 1992 and 1993 ERS-1 SAR acquisitions in Figure 4. The transect is $21 \mathrm{~km}$ in length and is located on Figure $3 \mathrm{~b}$. Figure 4 shows that the dark initial melt front (M) was present by mid-April in both 1992 and 1993. The M zone climbs rapidly in elevation and metamorphoses into the bright $\mathrm{P} 2$ zone, which is later encroached upon by bare glacier ice. The development and up-slope migration of these zones can be easily observed until late-September, at which point the accumulation of new snow and/or refreezing causes radar returns over the entire icefield to become erratic.

The topographic profile (inset, Fig. 4) of the radar backscatter transects was derived from the 1:50000 scale 104 B/ 11 and 104 B/14 Canadian topographic maps. The ice surface descends smoothly from 1850 to $580 \mathrm{~m}$ with a mean slope of $2.9^{\circ}$, except for a short reach at about $19 \mathrm{~km}$ where a slope of $16^{\circ}$ is found. Assuming equal slope in both the range and azimuth direction, the absolute error in $\sigma^{\circ}$ resulting from the pixel-area difference between the actual ice surface and a spherical earth model (van Zyl and others, 1993) is cal- culated at less than $\pm 1 \mathrm{~dB}$ over nearly all of the ice surface. This absolute error is much less than the $19 \mathrm{~dB}$ range of $\sigma^{\circ}$ variation observed between the four radar glacier zones $(-3$ to $-22 \mathrm{~dB})$. The effect of a steep icefall on the illuminated pizel-size calculation is found at $19 \mathrm{~km}$, where a consistent spike of high $\sigma^{\circ}$ can be seen in most of the backscatter transects (Fig. 4).

\subsection{Correlation of radar glacier zones with temper- atures and runoff}

Daily mean temperatures recorded at Bob Quinn Lake in 1992 and 1993 were used to calculate daily elevations of the $0^{\circ} \mathrm{C}$ isotherm, assuming a temperature lapse rate of $6.5^{\circ} \mathrm{C}$ $\mathrm{km}^{-1}$. Upper and lower boundary elevations for each radar glacier zone were estimated from 1:50000 topographic maps; these elevations are plotted with the isotherm elevations in Figure 5 for the 1992 and 1993 melt seasons. Estimated vertical clevation errors resulting from this procedure are also shown (except where boundary elevations exceed the maximum icefield elevation). Errors in point elevations determined from topographic maps are nearly insignificant, particularly since boundaries between radar glacier zones are not always sharp and may occur over a range of elevations as large as $200 \mathrm{~m}$.

Winter images over the icefield are characterized by uniform and high values of $\sigma^{\circ}(-3$ to $-7 \mathrm{~dB})$, in agreement with the results of Fahnestock and others (1993), Rott and Nagler
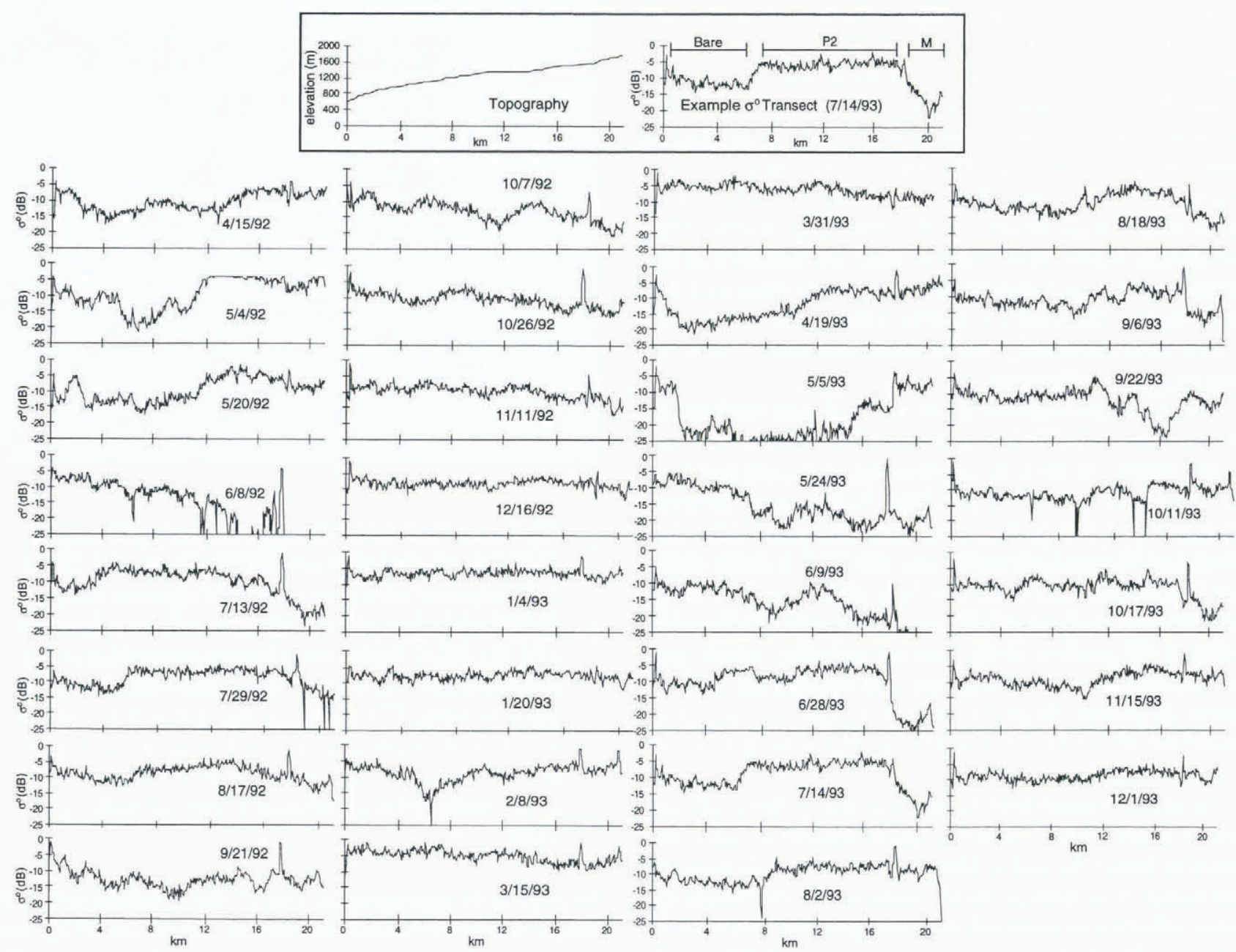

Fig. 4. Time series of ERS-1 SAR $\sigma^{\circ}$ transects between an outlet-glacier terminus $(0 \mathrm{~km})$ and the icefield interior $(21 \mathrm{~km})$. Transect location is shown in Figure $3 b$. Inset contains the transect topographic profile and a sample $\sigma^{\circ}$ transect showing the bare, P2 and $M$ radar glacier zones. 

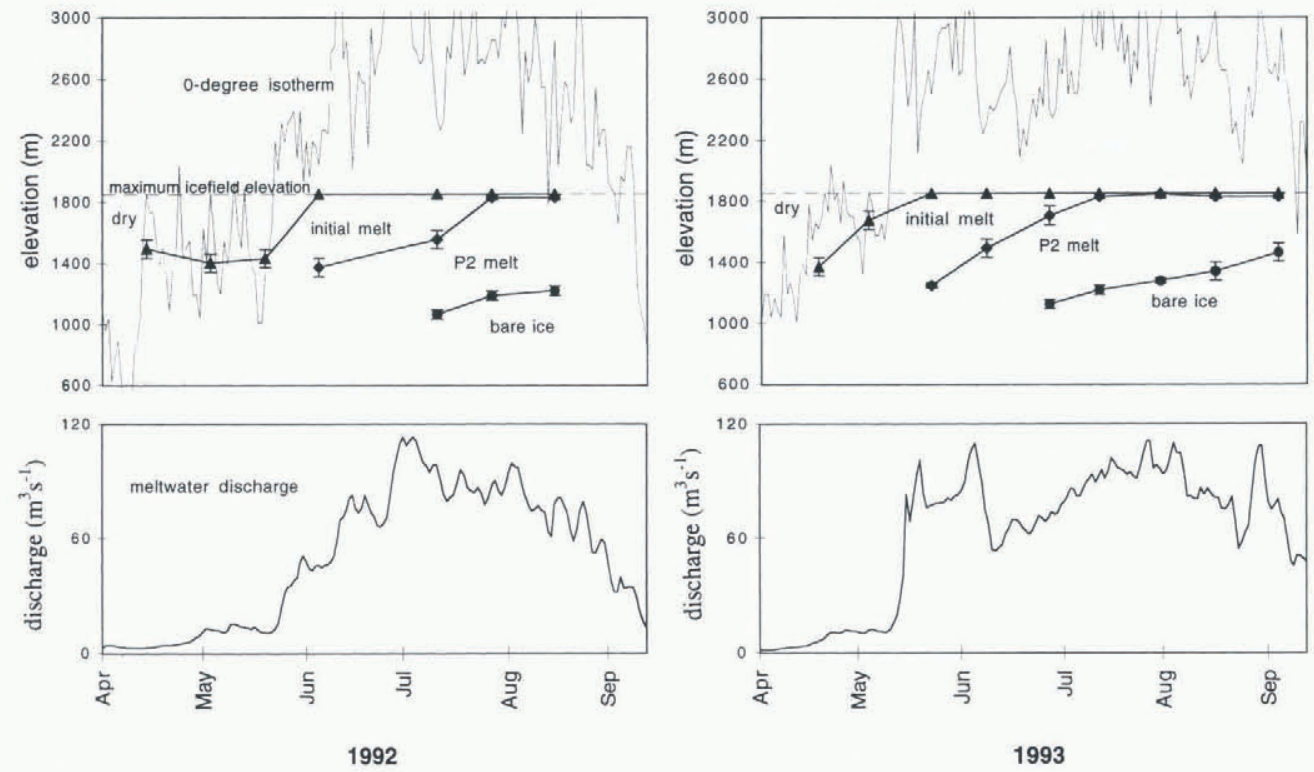

\begin{abstract}
Fig. 5. Time series for the 1992 and 1993 melt seasons of: (1) boundary elevations between the dry, M, P2 and bare radar glacier zones (each point is derived from a single ERS-1 SAR image); (2) daily elevations of the $0^{\circ}$ isotherm calculated from ground observations of air temperature; and (3) daily mean meltwater discharge measured in Forrest Kerr Creek.
\end{abstract}

(1994) and Rees and others (1995). High winter backscatter intensities likely result from low dielectric losses in dry snow and volume scattering from sub-surface ice lenses and pipes (Rott, 1994). The M zone appears by mid-April in both years. Its upper boundary is approximately coincident with the elevation of the $0^{\circ} \mathrm{C}$ isotherm until the isotherm exceeds the maximum elevation of the icefield. At this point, the upper limit of the $\mathrm{M}$ zone equals the maximum icefield elevation; its progress could undoubtedly be monitored further in time if the topography were higher. Metamorphosis of the $\mathrm{M}$ zone into $\mathrm{P} 2$ begins around 1 June. Bare glacier ice is first seen in early-July (1992) and late-June (1993). All four radar glacier zones rise steadily in elevation throughout the melt season until their obliteration in September.

Daily mean discharges of meltwater runoff from Forrest Kerr Creek are also shown in Figure 5. Flow routing was not applied to these data. Despite detection of internal meltwater storage in these glaciers (Tangborn, 1984), runoff is strongly correlated with air temperature. The appearance of the $\mathrm{M}$ zone precedes significant increases in stream flow by about 2 weeks. These higher flows are associated with the presence of a P2 zone but the temporal sampling of ERS-1 is not fine enough to determine whether $\mathrm{P} 2$ conditions must develop before large meltwater volumes are produced. However, it can be concluded from Figure 5 that increased meltwater production precedes the appearance of bare glacier ice by at least 1 month.

\subsection{ERS-1 SAR returns and field measurements from a melting snowpack}

Helicopter transport to a non-glacier snowpack located approximately $20 \mathrm{~km}$ from the primary study area (Fig. 1) permitted characterization of physical snow conditions within hours of an ERS-1 SAR acquisition on 8 June 1994. Nine snow pits were dug along a $500 \mathrm{~m}$ transect between the snowpack's maximum elevation and its lowest edge. Field measurements of snow depth, wetness, temperature, surface roughness and grain-size collected from these pits are given in Table 2. The surface roughness is characterized by the standard deviation of the surface height ( $\mathrm{rms}$ height $\sigma_{\mathrm{h}}$ ) and the correlation length $\left(l_{\mathrm{c}}\right)$ (Ulaby and others, 1982). The $\sigma_{\mathrm{h}}$ values at all locations are large enough to characterize the surface as "not smooth", based upon both the Rayleigh and the Fraunhofer criteria (Ulaby and others, 1982). The horizontal resolution of surface profiles was insufficient to separate $l_{\mathrm{c}}$ for several of the pits. The volumetric snow wetness $\left(W_{\mathrm{v}}\right)$ was measured with a Denoth dielectric meter (Denoth, 1989) near the surface and at depth. Mean surface snow-grain diameters were estimated from photographs of representative samples. High wetness values, observations of free water, and $0^{\circ} \mathrm{C}$ temperatures throughout the pits indicate that the snow pack was wet and melting at all depths (Table 2).

Low backscatter returns $(\approx-20 \mathrm{~dB})$ were recorded everywhere over the test site despite the range in snowpack properties given in Table 2. Ascending ERS-l SAR images acquired over this snowpack on 31 May, 8 and 25 June are given in Figure 6. Wet-snow extent at the test site is greatest on 19 May, reduced on 8 June, and nearly gone by 25 June. Meltwater discharge in Bronson Creek, the primary drainage from the test snowpack, was measured on 31 May and 1, 3, 5, 6 and 10 June using Price AA current meters. Measurements were carried out at approximately the same time each morning. Flows rose steadily during this time period $\left(4.5,4.8,5.3,6.0,6.4\right.$ and $\left.6.8 \mathrm{~m}^{3} \mathrm{~s}^{-1}\right)$. Discharge data were not collected during the 19 May and 25 June ERS-1 SAR acquisitions. However, the data do suggest that meltwater production increased while the extent of dark, melting snow at the test site and surrounding mountain slope decreased (Fig. 6).

\section{SIMULATION OF BACKSGATTER RETURNS USING A GEOMETRIC OPTICS MODEL}

This section presents simulated values of $\sigma^{\circ}$ generated by a model of radar backscattering from a wet snowpack. Field measurements described in section 4.3 are used as inputs. Simulated values of $\sigma^{\circ}$ agree with observed values from the $\mathrm{M}$ zone but are lower than those from the P2 zone.

In snowpacks with high liquid-water content and a rela- 
Table 2. Results of snow-pit measurements collected from a non-glacier snowpack within hours of an 8 June 1994 ERS-1 SAR acquisition. Surface roughness near the snow pit is characterized by the standard deviation of the mean surface height $\left(\sigma_{\mathrm{h}}\right)$ and the correlation length $\left(l_{\mathrm{c}}\right)$. Snow depths are based on five probe measurements made in the general areas of each snow pit. Volumetric snow wetness $\left(W_{\mathrm{V}}\right)$ is calculated from a capacitance wetness meter reading and snow density at upper $(2-5 \mathrm{~cm})$ and lower (26$34 \mathrm{~cm}$ ) snow depths. Snow wetness calculations for pits 6-9 use the mean density of pits 1-5. Error bounds on mean snow depth and grain-size are one standard deviation. Snow temperatures were measured between 26 and $34 \mathrm{~cm}$ in depth

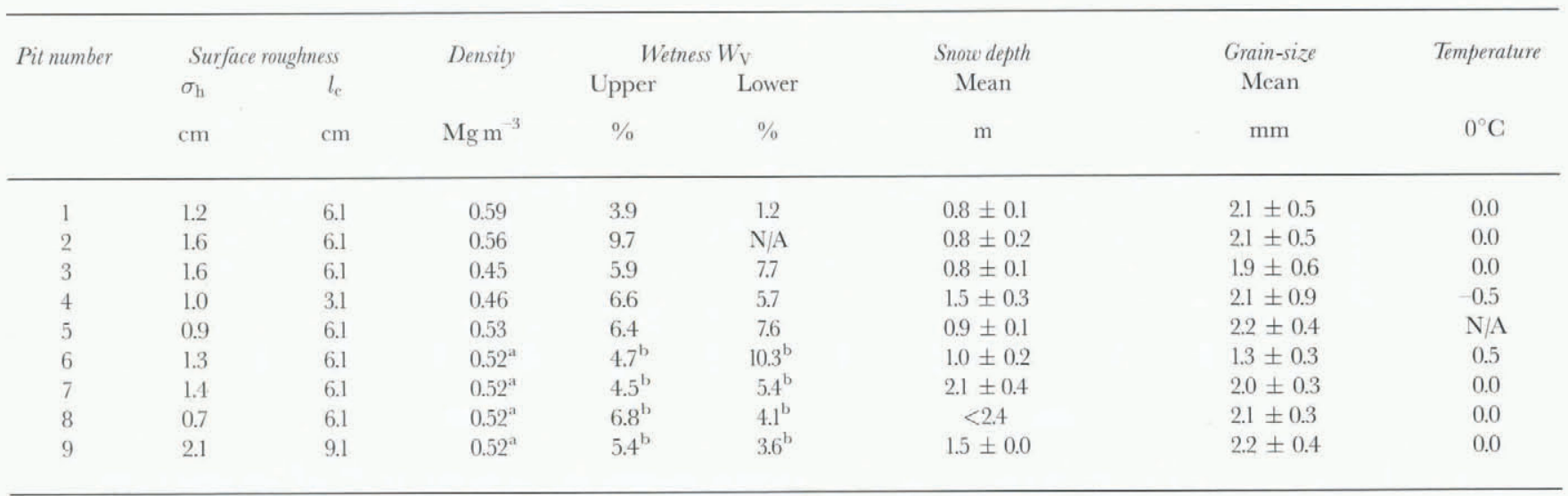

a Mean density.

${ }^{\text {b }}$ Uses mean density.
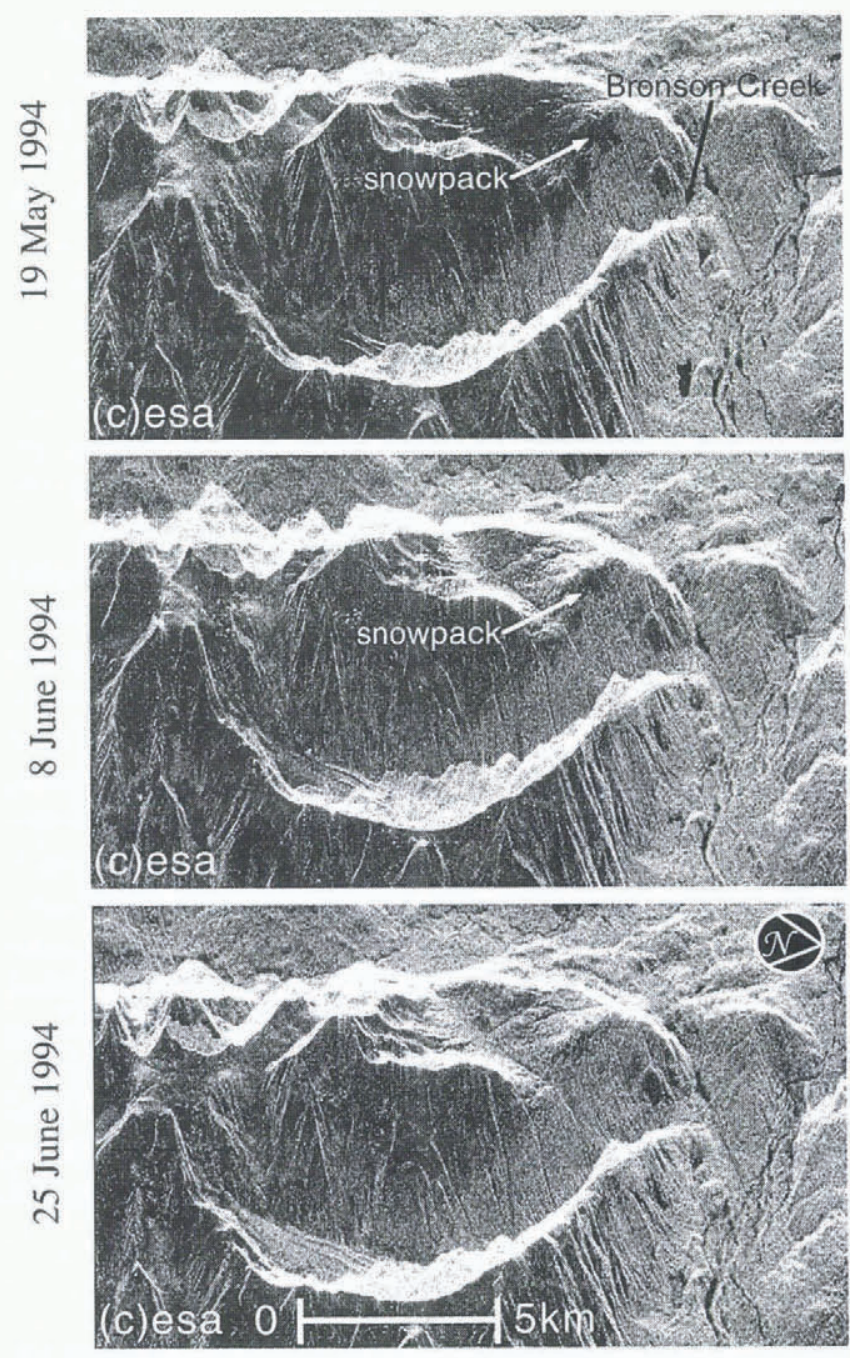

Fig. 6. Multi-temporal ERS-1 SAR images of the study snowpack (see arrow) and surrounding area. The extent of low radar returns is greatest on 19 May 1994, intermediate on 8 June and diminished by 25 June. Field measurements of snowpack properties given in Table 2 were collected within hours of the 8 fune image. Location of meltwater-discharge measurements made in Bronson Creek is also shown. Radar illumination is from the top of each image. tively rough surface, C-band surface scattering dominates over volume scattering at all incidence angles (Shi and Dozier, 1992). Here, we use a simple surfacescattering model (Jezek and others, 1993) to (1) compare ERS-1 backscatter intensities with values modeled for a wet alpine snowpack where ground measurements were obtained (Table 2); (2) estimate the range of surface conditions for the $\mathrm{M}$ zone; and (3) aid interpretation of the P2 zone. Model results are constrained by input values of snowpack surface roughness and dielectric constant. Surface roughness is parameterized as the rms slope of the surface. Assuming a Gaussian distribution of slopes, the rms slope () can be calculated as $1.14 \sigma_{\mathrm{h}} / l_{\mathrm{c}}$ (where $\sigma_{\mathrm{h}}$ is the standard deviation of the height and $l_{\mathrm{c}}$ is the correlation length). The dielectric constant is derived from the snow wetness and density through an empirical Debye-like model (Ulaby and others, 1986).

Simulations of $\sigma^{\circ}$ as a function of surface roughness for snowpacks of 6, 10 and 15\% wetness are shown in Figure 7 (average wetness measured in the field was 6\%). The input snow density of $0.52 \mathrm{Mg} \mathrm{m}^{-3}$ was obtained by averaging field measurements (Table 2). The input local incidence angle of $35^{\circ}$ combines the ERS- 1 incidence angle $\left(23^{\circ}\right)$ and the ground slope at the test area $\left(12^{\circ}\right)$. Ranges of rms slopes measured at the snow pits and ERS-1 SAR backscatter values recorded over the test site are also shown in Figure 7. The $\sigma^{\circ}$ values have been decreased by $2 \mathrm{~dB}$ to correct for the local slope effect (van Zyl and others, 1993).

Model results for the mean snow conditions measured at the site (wetness $=6 \%$, roughness slope $=17^{\circ}$, density $=$ $0.52 \mathrm{Mg} \mathrm{m}^{-3}$ ) are within $2 \mathrm{~dB}$ of the range of terrain-corrected $\sigma^{\circ}$ values measured by ERS-1. Also, the model predicts the backscatter at the minimum value of measured surface roughness to be well below the noise level of this ERS-1 scene. Over the test glaciers and icefield, ERS-1 $\sigma^{\circ}$ values $(-11$ to $-22 \mathrm{~dB})$ from the $\mathrm{M}$ zone are contained within the simulated range of $6-15 \%$ snowpack wetness. These results suggest that the model's assumptions of single scattering and Gaussian slopes are valid for freshly melting snow.

However, the geometric optics model fails to simulate the high $\sigma^{\circ}$ returns $(-6$ to $-8 \mathrm{~dB})$ from the $\mathrm{P} 2$ zone. Forcing 


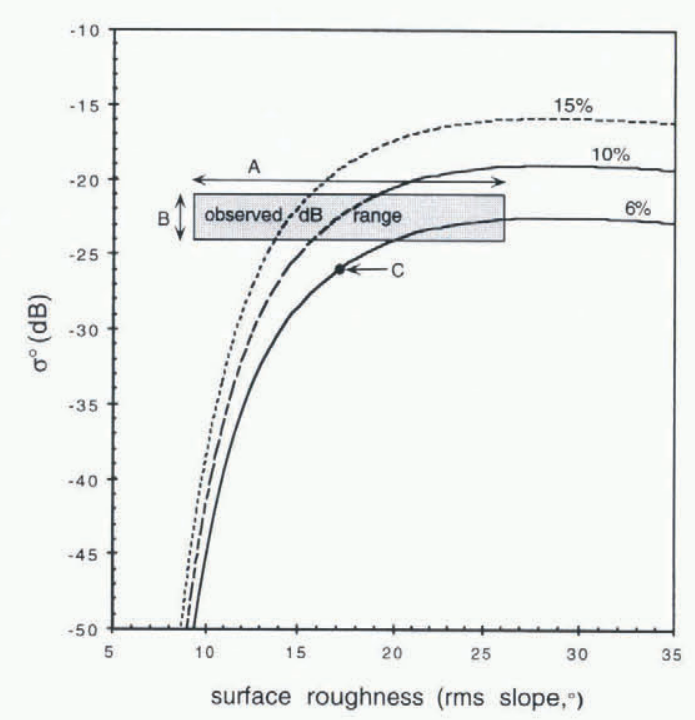

Fig. 7. Simulated $C-V V \sigma^{\circ}$ curves for three wet snowpacks (liquid water contents: 6,10 and $15 \%$ ), using a geometric optics model of radar backscattering. Increased backscatter is associated with increased surface roughness and liquid-water content. The ranges of surface roughness measured on the ground on 8 fune $1994(A)$ and observed $\sigma^{\circ}$ recorded hours later $(B)$ are also shown. Model value of $\sigma^{\circ}$ simulated using average density $\left(0.52 \mathrm{Mg} \mathrm{m}^{3}\right)$ and incidence angle $\left(35^{\circ}\right)$ measured at the test site is shown at $(C)$.

snow-wetness values above $15 \%$ is physically unreasonable and increasing surface slopes only decreases $\sigma^{\circ}$. Increasing snow density to $0.7 \mathrm{Mg} \mathrm{m}^{-3}$ increases the $15 \%$ wetness return by only $1 \mathrm{~dB}$. Changing the incidence angle to $23^{\circ}$ and terrain correcting for the mean glacier slope $\left(3^{\circ}\right)$ also increases the returns only slightly. The highest $\sigma^{\circ}$ value the model predicts for snow wetness not exceeding $15 \%$ is only $-13 \mathrm{~dB}$.

This failure may result from the model's assumption of single-path scattering. To simulate $\sigma^{\circ}$ returns from P2-type surfaces, a model that considers multiple scattering, such as the integral equation model (Fung and others, 1992), may be required. Rough, wet-snow surface conditions that could induce multiple-path scattering (and hence strong backscatter) include sun cups, penitente snow, ploughshares, perforated crust and suncrust. A hydrological mechanism that may induce multiple-path scattering and also promote a rough surface is the draining of surface meltwater into the snowpack. This process can form vertical pipes of liquid water in the sub-surface, creating areas of sharp dielectric contrast and strong radar returns (Kattelmann, 1995; Shi and Dozier, 1996). Development of a vertical drainage system would also contribute to the increased meltwater discharge observed during P2 conditions (Fig. 5).

\section{DISCUSSION}

Radar glacier zones are formed by important physical processes that occur at the glacier surface, particularly surface melt and snow diagenesis. While this information cannot be used to estimate glacier mass balance directly, variability in these processes can be observed and related to changing climatic conditions that do affect mass balance (Fahnestock and others, 1993). For example, Forster and others (1996, 1997) identified seasonal trends and short-term weather effects, respectively, from SIR-C/X-SAR data acquired over Hielo Patagónico Sur (southern Patagonia icefield), providing a regional interpretation of the climatic regime over the icefield. Our own findings suggest that orbital SAR may be used to establish the timing of melt onset over glaciers. Support for this statement is provided by Winebrenner and others (1994), who found a close correlation between steep decreases in ERS-1 SAR backscatter over sea ice and the onset of $0^{\circ} \mathrm{C}$ (or higher) temperatures recorded by six drifting buoys in the Beaufort Sea.

In agreement with the results of Rees and others (1995), we find that SAR may be used to monitor the position of the transient snowline on large glaciers. This may have value in efforts to monitor glacier mass balance. Equilibrium-line altitude (ELA) can in many cases be approximated as the position of the late-summer snowline (Ostrem, 1975; Ostrem and Brugman, 1991). ELA is in turn related to glacier mass balance (Ostrem, 1975; Braithwaite, 1984), although some glaciers require knowledge of the transient snowline and the ELA at different times during the ablation season to determine mass balance (Pelto, 1987). For the study site, the maximum late-summer snowline elevations in 1992 and 1993 derived from ERS-1 SAR imagery were $1220 \mathrm{~m}$ and $1460 \mathrm{~m}$, respectively. The ELA of the nearby Porcupine Glacier has previously been estimated at $1400 \mathrm{~m}$ (Pelto, 1987). The closeness of these values suggests a potential use for SAR in complementing ELA-monitoring programs.

Comparison of air temperature and runoff measurements with patterns of M-zone development suggest that only a thin layer of surface melting is required to sharply decrease $\sigma^{\circ}$ over snow. The appearance of the $\mathrm{M}$ zone is correlated with the first arrival of above-freezing temperatures and precedes increased stream flow by around 2 weeks. ERS-1 SAR images acquired on 19 May, 8 and 25 June 1994 over a nearby non-glacierized snowpack show a diminishing area of low radar returns. Field measurements on this snowpack collected on 8 June indicate that by this time it was rapidly melting and $0{ }^{\circ} \mathrm{C}$ throughout. Meltwater discharge measured in Bronson Creek increased steadily between 31 May and 10 June, suggesting that maximum runoff production occurs later than peak extent of low radar returns. The $\mathrm{P} 2$ zone may be correlated with high meltwater production but more work is needed to determine the relationship between the evolution of radar glacier zones and meltwater discharge in streams.

\section{CONGLUSION}

35 ERS-1 SAR scenes of an icefield and two outlet glaciers reveal the temporal and spatial evolution of four zones related to surface wetness and textural properties. They appear, migrate up-elevation and disappear in response to spring and summer melting. Boundaries between these zones appear to represent: (1) the $0^{\circ} \mathrm{C}$ isotherm; (2) a diffuse transition between fresh wet snow and rough wet snow; and (3) snowline. After the first few weeks of melting each year, high backscatter returns $(-6$ to $-8 \mathrm{~dB})$ are found over firstyear snow. A proposed mechanism for these high radar returns is multiple-path scattering from a wet, pitted snow surface. Meltwater volumes delivered to streams are sensitive to the occurrence of these zones. Increased stream flow begins about 2 weeks after the initiation of melting on the glacier surface. 


\section{ACKNOWLEDGEMENTS}

Support for this work was provided by NASA through Earth Observing System (EOS) grant NAGW-2638, Spaceborne Imaging Radar (SIR-C) grant 958745 and a Graduate Student Researchers Program Fellowship NGT-51223. ERS-1 data were provided by the European Space Agency and acquired by the NASA/Alaska SAR Facility. Hovercraft and helicopter transport was generously donated by Cominco Snip Operation and Pamicon Inc. The Denoth snow-wetness meter was provided by R. Davis at the U.S. Army Cold Regions Research and Engineering Laboratory. Assistance from T. Blodgett, S. Das, A. Krat, J. Liebeskind and I. Preuss is gratefully acknowledged. Interpretation of P2 backscatter returns was aided by discussions with $\mathrm{M}$. Miller (Glaciological and Arctic Sciences Institute, University of Idaho) and J. Dozier (School of Environmental Science and Management, University of California, Santa Barbara).

\section{REFERENCES}

Benson, C. S. 1962. Stratigraphic studies in the snow and firn of the Greenland ice sheet. SIPRE Res. Rep. 70.

Bicknell, T. 1992. User's guide to products, Alaska SAR facility SAR processor system. Version 1.0. Pasadena, CA, Jet Propulsion Laboratory. (Report JPL D9362.)

Bindschadler, R. A. and P. L. Vornberger. 1992. Interpretation of SAR imagery of the Greenland ice sheet using coregistered TM imagery. Remote Sensing Environ., 42(3), 167-175.

Braithwaite, R. J. 1984. Can the mass balance of a glacier be estimated from its equilibrium-line altitude? J. Glaciol., 30 (106), $364-368$.

Denoth, A. 1989. Snow dielectric measurements. Adv. Space Res., 9(1), 233243.

Donald, J. R., F. R. Seglenieks, E. D. Soulis, N. Kouwen and D.W. Mullins. 1993. Mapping partial snowcover during the melt season using C-band SAR imagery. Can. 7. Remote Sensing, 19 (1), 68-76.

Dowdeswell, J. A., W. G. Rees and A. D. Diament. 1994. ERS-1 SAR investigations of snow and ice facies on ice caps in the European High Arctic. In Space at the Service of our Environment. Proceedings of the Second ERS-I Symposium, 11-14 October 1993, Hamburg, Germany. Vol. 2. Paris, European Space Agency, 1171-1176. (ESA SP-361.

Fahnestock, M., R. Bindschadler, R. Kwok and K. Jezek. 1993. Greenland ice sheet surface properties and ice dynamics from ERS-1 SAR imagery. Science, 262 (5139), 1530-1534.

Forster, R.R., B.L. Isacks and S. Das. 1996. Shuttle imaging radar (SIR-C) $\mathrm{X}-\mathrm{SAR}$ ) reveals near surface properties of the South Patagonian Icefield. 7. Geophys. Res., 101 (E10), 23,169-23,180.

Forster, R. R., L. C. Smith and B. L. Isacks. 1997. Effects of weather events on X-SAR returns from ice fields: case-study of Hielo Patagónico Sur, South America. Ann. Glaciol., 24, 367-374.

Fung, A. K., Z. Li and K. S. Chen. 1992. Backscatter from a randomly rough dielectric surface. IEEE Trans. Geosci. Remote Sensing, GE- 30 (2), 356-369.

Haeberli, W., P. Müller, P. Alean and H. Bösch. 1989. Glacier changes following the Little Ice Age - a survey of the international data basis and its perspectives. In Oerlemans, J., ed. Glacier fluctuations and climatic change. Dordrecht, etc., Kluwer Academic Publishers, 77-101.

Haefner, H., F. Holecz, E. Meier, D. Nüesch and J. Piesbergen. 1994. Capabilities and limitations of ERS-1 SAR data for snowcover determination in mountainous regions. In Space at the Service of our Environment. Proceedings of the Second ERS-1 Symposium, 11-14 October 1993, Hamburg, Germany. Vol. 2. Paris, European Space Agency, 971-976. (ESA SP-361.)

Hall, D. K., R. S. Williams, Jr and O. Sigur 5 sson. 1995. Glaciological observations of Bruarjökull, Iceland, using synthetic aperture radar and thematic mapper satellite data. Ann. Glaciol., 21, 271-276.

Hallikainen, M., V. Jääskeläinen, L. Kurvonen, J. Koskinen, E. -A. Herland and J. Perälä. 1993. Application of ERS-I SAR data to snow mapping. In Kaldeich, B., ed. Proceedings of the First ERS-1 Symposium Space at the Service of our Environment, 4 - 6.November 1992, Cannes, France. Vol. 2. Paris, European Space Agency, 589-594. (ESA Special Publication SP-359.)

Jezek, K. C., M. R. Drinkwater, J. P. Crawford, R. Bindschadler and R. Kwok. 1993. Analysis of synthetic aperture radar data collected over the southwestern Greenland ice sheet. f. Glaciol., 39(131), 119-132.
Kattelmann, R. C. 1995. Water movement and ripening processes in snowpacks of the Sierra Nevada. (Ph.D. thesis, University of California, Santa Barbara.)

Maxfield, A.W. 1994. Radar satellite snowmelt detection in the Canadian Rocky Mountains. In Stein, T. I., ed. IGARSS '94. Surface and Atmospheric Remote Sensing: Technologies, Data Analysis and Interpretation, Pasadena, California Institute of Technology, California, USA, August 8-12, 1994. Proceedings. Vol.4. Pisacataway, NJ, Institute of Electrical and Electronics Engineers, 2074-2077.

Meier, M. F. 1984. Contribution of small glaciers to global sea level. Science, 226 (4681), 1418-1421.

O'Connor, J. E. and J. E. Costa. 1993. Geologic and hydrologic hazards in glacierized basins in North America resulting from 19th and 20th century global warming. Natural Hazards, 8 2, 121-140.

Ostrem, G. 1975. ERTS data in glaciology — an effort to monitor glacier mass balance from satellite imagery. f. Glaciol., 15 (73), 403-415.

Ostrem, G. and M. Brugman. 1991. Glacier mass-balance measurements. A manual for field and office work. Saskatoon, Sask., Environment Canada. National Hydrology Research Institute. (NHRI Science Report 4.)

Pelto, M. S. 1987. Mass balance of south-east Alaska and north-west British Columbia glaciers from 1976 to 1984: methods and results. Ann. Glaciol., 9, $189-194$.

Pelto, M. S. 1989. Satellite determination of Coast Range, Alaskan glacier mass balance related to atmospheric circulation. International Association of Hydrological Sciences Publication 186 (Symposium at Baltimore 1989 Remote Sensing and Large-Scale Global Processes), 127-137.

Rees, W. G., J. A. Dowdeswell and A. D. Diament. 1995. Analysis of ERS-1 synthetic aperture radar data from Nordaustlandet, Svalbard. Int. 7. Remote Sensing, 16 (5), 905-924.

Rignot, E. 1995. Backscatter model for the unusual radar properties of the Greenland ice sheet. 7. Geophys. Res., 100 E5), 9389-9400.

Rott, H. 1994. Thematic studies in alpine areas by means of polarimetric SAR and optical imagery. Adv. Space Res., 14(3), 217-226.

Rott, H. and R. E. Davis. 1993. Multifrequency and polarimetric SAR obervations on alpine glaciers. Ann. Glaciol., 17, 98-104.

Rott, H. and C. Mätzler. 1987. Possibilities and limits of synthetic aperture radar for snow and glacier surveying. Ann. Glaciol., 9, 195-199.

Rott, H. and T. Nagler. 1993. Snow and glacier investigations by ERS-1 SAR - first results. In Kaldeich, B., ed. Proceedings of the First ERS-1 Symposium Space at the Service of our Environment, 4 - 6 November 1992, Cannes, France. Vol. 2. Paris, European Space Agency, 577-582. (ESA Special Publication SP-359.

Rott, H. and T. Nagler. 1994. Capabilities of ERS-1 SAR for snow and glacier monitoring in alpine areas. In Space at the Service of our Environment. Proceedings of the Second ERS-1 Symposium, 11-14 October 1993, Hamburg, Germany. Vol. 2. Paris, European Space Agency, 965-970. (ESA SP-361.)

Shi Jiancheng and J. Dozier. 1992. Radar backscattering response to wet snow. In Williamson, R., ed. IGARSS'92. International Space Year: Space Remote Sensing, Houston, Texas, May 26-29, 1992. Proceedings. Vol. 2. New York, Institute of Electrical and Electronics Engineers, 927-929.

Shi Jiancheng and J. Dozier. 1993. Measurements of snow- and glacier-covered areas with single-polarization SAR. Ann. Glaciol., 17, 72-76.

Shi Jiancheng andJ. Dozier. 1995. Inferring snow wetness using C-band data from SIR-C's polarimetric synthetic aperture radar. IEEE Trans. Geosci. Remote Sensing, GE-33 (4), 905 - 914. (Correction: GE-33 6), 1995, 1340.)

Shi Jiancheng, J. Dozier and H. Rott. 1993. Deriving snow liquid water content using C-band polarimetric SAR. In IGARSS'93. Better Understanding of Earth Environment, Tokyo, Japan, 18-21 August 1993. Proceedings. Vol. 3. New York, Institute of Electrical and Electronics Engineers, 1038-1041.

Tangborn, W.V. 1984. Prediction of glacier derived runoff for hydroelectric development. Geogr. Ann., 66A (3), 257-265.

Ulaby, F. T., R. K. Moore and A. K. Fung, eds. 1982. Radar remote sensing and surface scattering and emission theory. Vol. 2. Reading, MA, Addison-Wesley Publishing Co.

Ulaby, F. T., R. K. Moore and A. K. Fung. 1986. Microwave remote sensing: active and passive. Vol.3. Dedham, MA, Artech House.

Van Zyl, J., B. Chapman, P. Dubois and J. Shi. 1993. The effect of topography on SAR calibration. IEEE Trans. Geosci. Remote Sensing, GE-31 (5), 1036-1043.

Winebrenner, D. P., E. D. Nelson, R. Colony and R. D. West. 1994. Observation of melt onset on multiyear Arctic sea ice using the ERS 1 synthetic aperture radar. J. Geophys. Res., 99 (Cl1), 22,425-22,441.

Yarnal, B. 1984. Relationships between synoptic-scale atmospheric circulation and glacier mass balance in south-western Canada during the International Hydrological Decade, 1965-74. J. Glaciol., 30 (105), 188-198.

Young, G. J., ed. 1985. Techniques for prediction of runoff from glacierized areas. Wallingford, Oxon., International Association of Hydrological Sciences. (IAHS Publication 149. 